\title{
PEMBUATAN ALAT PEMISAH BUAH KOPI OTOMATIS BERDASARKAN WARNA MENGGUNAKAN SENSOR WARNA TCS230 BERBASIS MIKROKONTROLER
}

\author{
Ahyuna $^{1}$, Herlinda ${ }^{2}$ \\ Dosen STMIK Dipanegara Makassar ${ }^{1,2}$ \\ Jalan Perintis Kemerdekaan Km.9 Makassar \\ Sur-el :Ahyuna@dipanegara.ac.id ${ }^{1}$, herlinda_dp@yahoo.com²
}

\begin{abstract}
Separation of ripe and unripe coffee beans manually can affect human emotions, can reduce the effectiveness and time efficiency of coffee farmers, so as to make the quality of coffee quality is not guaranteed. With this tool, it will be able to select the coffee fruit automatically which can streamline the time of coffee farmers and help improve the process of processing coffee fruit. This tool will work by selecting the color of red coffee which means ripe and green means not yet ripe, this tool is equipped with a motor to separate coffee fruit, a color sensor Tcs230 to select coffee fruit, and a container that has been prepared to store ripe and immature coffee fruit, by separating at the two levels of classification of coffee fruit.
\end{abstract}

Keywords: Coffee fruit separator, Color Sensor Tcs230, microcontroler

\begin{abstract}
Abstrak : Pemisahan buah kopi yang matang dan tidak matang secara manual dapat mempengaruhi emosi manusia, dapat mengurangi efektifitas dan efisiensi waktu para petani buah kopi, sehingga dapat membuat mutu kopi tidak terjamin kualitasnya. Dengan adanya alat ini akan mampu menyeleksi buah kopi secara otomatis yang dapat mengefisienkan waktu petani kopi dan membantu peningkatan proses dalam pengolahan buah kopi. Alat ini akan bekerja dengan menyeleksi warna buah kopi yang merah yang berarti matang dan warna hijau berarti belum matang, pada alat ini dilengkapi dengan motor penggerak untuk memisahkan buah kopi, sebuah sensor warna Tcs230 untuk menyeleksi buah kopi, dan sebuah wadah yang telah disiapkan untuk menyimpan buah kopi yang matang dan tidak matang, dengan melakukan pemisahan pada kedua tingkat klasifikasi buah kopi.
\end{abstract}

Kata kunci: Alat Pemisah buah Kopi, Sensor Warna Tcs230, Mikrokontroler

\section{PENDAHULUAN}

Kopi adalah salah satu minuman instan yang banyak di gemari masyarakat. Sebelum menjadi minuman yang siap disajikan, kopi memerlukan beberapa tahapan proses dalam pengolahan, diantaranya yaitu pemilihan kualitas biji kopi yang dipetik, pengeringan, dan tahapan akhir yaitu penyangraian. Pada tahap penyangraian, kopi di sangrai hingga mencapai tingkat kematangan sempurna. Terdapat beberapa faktor yang mempengaruhi tingkat kematangan kopi, diantaranya suhu, warna, waktu dan jumlah kopi yang di sangrai dalam satu mesin sangrai kopi.

Banyak petani yang memetik kopi secara serentak hingga bercampurnya buah kopi yang masih hijau dan yang sudah merah hingga menyebabkan kualitas rasa yang kurang baik. Kopi sudah matang sempurna adalah kopi yang berwarna merah penuh memiliki cita rasa dan aroma yang paling bagus. Kopi yang terlalu matang atau berwarna merah tua menghasilkan biji kopi berwarna cokelat kehitaman Kopi semacam ini akan menghasilkan cita rasa seperti bau tanah. hanya buah kopi yang berwarna 
merah penuh yang akan menghasilkan kopi yang berkualitas, sedangkan kopi yang muda memiliki kualitas rendah, dan tidak ada yang bisa kita lakukan untuk meningkatkan kualitas kopi tersebut. Kopi yang hijau (muda), secara umum akan menghasilkan rasa yang tidak enak, kurang manis dan memiliki sensasi astringent (menciutkan rasa). Kopi matang, memiliki kandungan gula dan air yang seimbang.

Untuk itu dirancang sebuah Alat Pemisah Buah Kopi Otomatis Berdasarkan Warna Mnggunakan Sensor Warna Tcs230 Berbasis Mikrokontroler agar dapat mengefesienkan waktu para petani untuk menjaga mutu kualitas terbaik dari buah kopi.

Ada beberapa penelitian yang terkait mengenai Alat Pemisah Kopi ini sebagai sistem otomatisasi untuk meningkatkan kulitas dari buah kopi, dalam upaya menyempurnakan dan mengembangkan Alat Pemisah Biji Kopi maka dilakukanlah studi pustaka, yaitu :

1. Alat Penyortir Dan Pengecekan Kematangan Buah Menggunakan Sensor Warna, oleh Dimas Rizki Radityo, Muhammad Riyan Fadillah, Quincy Igwahyudi, Satrio Dewanto. Alat ini mengidentifikasi buah matang berdasarkan warna kemudian mengeluarkan hasil keputusan yang diambil dari input sensor warna tcs3200 dan melakukan sortir secara manual. [1]

2. Rancang Bangun Alat Pendeteksi Kematangan Buah Apel Dengan Menggunakan Metode Image Processing Berdasarkan Komposisi Warna, oleh Sunu Jatmika, Dwi Purnamasari. Penentukan kematangan apel dari kamera dengan mengambil foto dari apel yaitu dengan cara menghitung nilai jarak antar histogram yang dihasilkan oleh kedua citra. Citra yang memiliki kemiripan distribusi warna citra yang sama persis memiliki selisih jarak sama dengan nol. Dari hasil pengujian juga didapatkan bahwa ada beberapa faktor yang mempengaruhi keakuratan yaitu cahaya, jarak, dan background. [2]

3. Prototipe Alat Pendeteksi Kematangan Buah Terong Belanda (Chypomandra Betacea) Berdasarkan Warna Menggunakan Mikrokontroler Atmega328, oleh Mutiara Ningsih, Herriza Nur, Nurul Zecha, Sri Fitria R., S.Si, M.T, Shabri Putra Wirman, M.Si.Metode yang digunakan adalah melihat warna dari buah yang menjadi objek penelitian dan membuat keputusan berdasarkan hasil yang diperoleh dari sensor kemudian menentukan buah matang atau tidak.

\section{METODOLOGI PENELITIAN}

Pada penelitian iniada 2 pendekatan yang digunakan untuk memperoleh data / informasi diantaranya adalah :

\section{Metode Pustaka}

Penelitian yang dilakukan dengan mengambil beberapa referensi dan rujukan mengenai defenisi serta konsep yang berhubungan dengan penelitian.

2. Metode dokumentasi yaitu mengumpulkan dokumen arsip yang berhubungan dengan prototype pemisah buah kopi.

Adapun bahan penelitian yang dibutuhkan yaitu:

1. Isolasi yaitu, digunakan untuk sambungan kabel.

2. Timah Solder yaitu, alat bantu dalam merakit atau membongkar rangkaian elektronika pada rangkaian yang terdapat pada papan PCB. 
3. Arduino yaitu salah satu papan pengembangan mikrokontroller yang berukuran kecil, lengkap dan mendukung penggunaan breadboard.

4. Kabel sebagai media transmisi.

5. Mur yaitu untuk menggabungkan beberapa komponen sehingga tergabung menjadi satu bagian yang memiliki sifat tidak permanen.

6. Baut yaitu sebagai pengikat (fastener) untuk menahan dua obyek Bersama.

7. Motor Servo yaitu sebagi sistem kontrol umpan balik loop tertutup (servo), sehingga dapat di set-up atau di atur untuk menentukan dan memastikan posisi sudut dari poros output motor.

8. Triplex untuk membuat rangka.

9. Lem Kayu sebagai perekat.

10. Sensor warna TCS230 untuk mengkonversi warna yang akan dideteksi menjadi Frekuensi yang akan diolah oleh mikrokontroler.

11. Power Supply yaitu alat yang mampu memberikan sebuah suplai arus listrik kepada semua komponen komputer yang sudah terpasang dengan baik, dimana arus listrik yang dihasilkan merupakan arus $\mathrm{AC}$ dan selanjutnya akan dirubah menjadi arus DC.

\subsection{Sensor warna TCS230}

Sensor warna TCS230 adalah sensor warna yang sering digunakan pada aplikasi mikrokontroler untuk pendeteksian suatu objek benda atau warna sari objek yang dimonitor. Sensor warna TCS230 juga dapat digunakan sebagai sensor gerak, dimana sensor mendeteksi gerakan suatu objek berdasarkan perubahan warna yang diterima oleh sensor [3]. IC TCS230 dapat dioperasikan dengan supply tegangan pada Vdd berkisar antara 2,7Volt - 5,5 volt, dalam pengoperasiannya sensor tersebut dapat dilakukan dengan dua cara yaitu dengan mode supply tegangan maksimum, yaitu dengan menyuplai tegangan berkisar antara 2,7volt $-5,5$ volt pada sensor warna TCS230 dan mode supply tegangan minimum, yaitu dengan menyuplai tegangan 0 sampai 0,8 .Sensor warna TCS230 terdiridari 4 kelompok photodiode. [4][5]

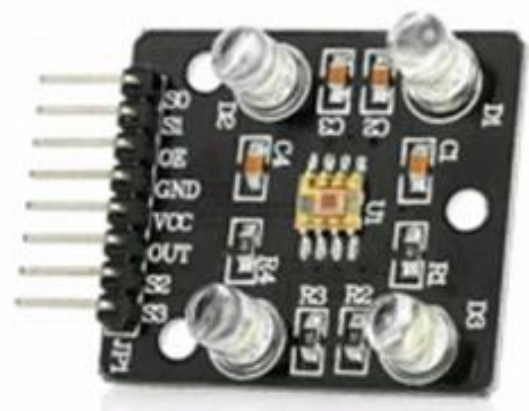

\section{Gambar 1. Bentuk fisik sensor TCS230 [1]}

\subsection{Mikrokontroler AVR ATMega 8535}

Mikrokontroler merupakan keseluruhan system komputer yang dikemas menjadi sebuah chip di mana di dalamnya sudah terdapat mikroprosesor, I/O, memori bahkan ADC, berbeda dengan mikroprosesor yang berfungsi sebagai pemroses data. Mikrokontroler AVR (Alf and Vegard's Risc processor) memiliki arsitektur 8 bit, dimana semua instruksi dikemas dalam kode 16-bit dan sebagian besar instruksi dieksekusi dalam 1 siklus clock atau dikenal dengan teknologi RISC (Reduced Instruction Set Computing). Pada mikrokontroler dengan teknologi RISC semua intruksi dikemas dalam kode 16 bit (16 bits words) dan sebagaian besar intruksi dieksekusi dalam 1 clock, sedangkan 
pada teknologi CISC seperti yang diterapkan pada mikrokontroler MCS-51, untuk menjalankan sebuah intruksi dibutuhkan waktu sebanyak 12 siklus clock. [5]

\subsection{Mikrokontroler AVR ATMega 8}

Jika Mikrokontroler $A V R$ ini memiliki arsitektur RISC (Reduce Instruction Set computing) delapan bit, dimana semua instruksi dikemas dalam kode 16-bit (16 bits word) dan sebagian besar instruksi dieksekusi dalam 1 (satu) siklus clock. ATMega 8 memiliki ukuran fisik lebih kecil dibandingkan beberapa mikrokontroler lainnya. Namun untuk segi memori dan peripherialnya hampir sama.

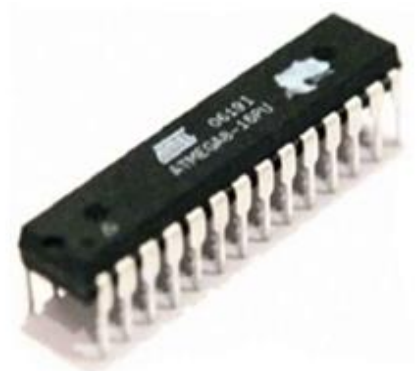

\section{Gambar 2. Bentuk fisik IC Mikrokontroler} ATMega 8 [3]

\subsection{Uno Arduino}

Uno Arduino adalah board berbasis mikrokontroler pada ATmega328. Board ini memiliki 14 digital input / output pin (dimana 6 pin dapat digunakan sebagai output PWM), 6 input analog, $16 \mathrm{MHz}$ osilatorkristal, koneksi USB, jack listriktombol reset. Pin-pin ini berisi semua yang diperlukan untuk mendukung mikrokontroler, hanya terhubung kekomputer dengan kabel USB atau sumber tegangan biasa didapat dari adaptor AC-DC atau baterai untuk menggunakannya. Tegangan bias didapat dari adaptor AC-DC atau baterai untuk menggunakannya. Board Arduino Uno memiliki fitur-fitur baru sebagai berikut : - 1,0 pinout: tambah SDA dan SCL pin yang dekat ke pin aref dan dua pin baru lainnya ditempatkan dekatke pin RESET, dengan IO REF yang memungkinkan sebagai buffer untuk beradaptasi dengan tegangan yang disediakan dari board sistem. Pengembangannya, sistem akan lebih kompatibel dengan Prosesor yang menggunakan AVR, yang beroperasi dengan $5 \mathrm{~V}$ dan dengan Arduino Karena yang beroperasi dengan 3.3V. Yang kedua adalah pin tidak terhubung, yang disediakan untuk tujuan pengembangannya. [6]

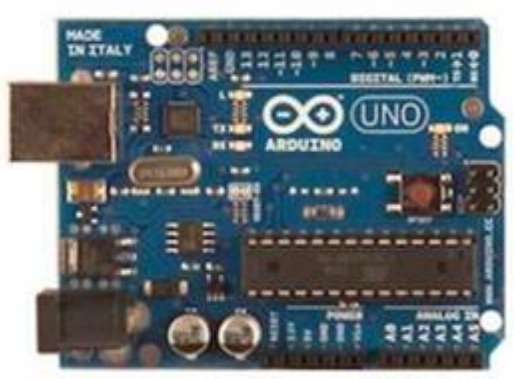

Gambar 3. Board Arduino Uno [6]

\section{HASIL DAN PEMBAHASAN}

Gambar 4 merupakan Blok diagram untuk alat pemisah buah kopi berdasarkan warna menggunakan sensor warna tcs230. Keterangan gambar dari blok diagram pemisah buah kopi :

1. Buah kopi dari pohon kopi yang akan dipisahkan sebagai masukan dari alat pemisha buah kopi.

2. Motor servo pertama akan mengantar buah kopi yang dimasukan menuju sensor warna untuk diambil warnanya 
3. Sensor warna mengambil warna dari buah kopi kemudain mengirim data warna ke arduino untuk di proses.

4. Arduino uno selanjutnya melakukan proses penentuan buah kopi matang atau tidak matang.

5. Motor servo kedua mengarahkan kopi menuju wadah yang disediakan untuk buah matang atau yang tidak matang.

6. Pin Vin adalah pin yang digunakan untuk memasukkan daya kearduino nano sebesar lima volt dan sebagai sumber tegangan dari modul yang digunakan.

7. GND, yaitu pin yang terhubung ke arus negatif (-) sumber tegangan.

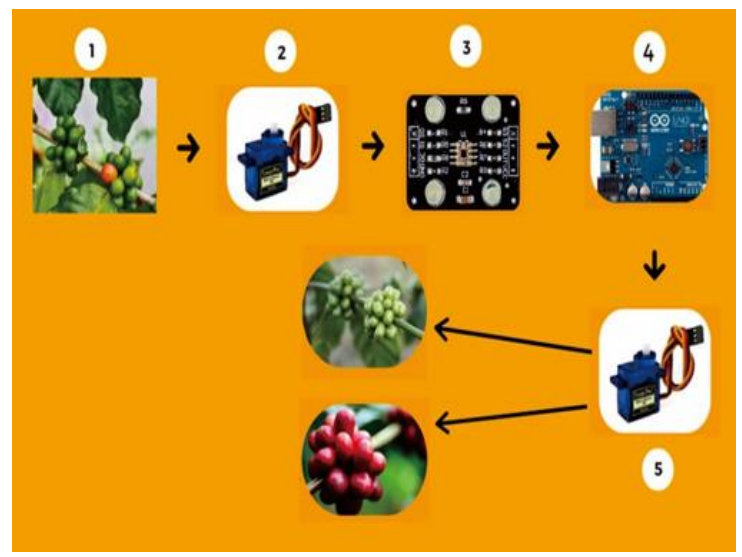

Gambar 4. Blok Diagram

Gambar 5 menunjukan hasil alat pemisah buah kopi. Keterangan gambar dari Alat Pemisah Buah Kopi yaitu:

1. Coron kopi, tempatmemasukkankopi yang akan dipisahkan.

2. Servo ketiga yang diletakkan pada corong buah kopi yang akan dipilih warna dari buah kopi sebagai yang berfungsi sebagai penggerak kopi untuk membantu proses membawa kopi ke sensor.
3. Stan sensor warna tes230, diletakkan tepat diatas servo 1 untuk membaca warna kopi.

4. Motor servo pertama, sebagai pengantar biji kopi dari corong penampungan menuju sensor warna.

5. Motor Servo kedua sebagai corong untuk mengarahkan kopi menuju wadah yang matang, belum matang atau wadah yang warna kopinya tidak teridentifikasi (rusak).

6. Rangkain alat pemisah buah kopi, tempat untuk mendapatkan daya agar setiap modul yang terpasang terhubung kesemua komponen untuk saling berkomunikasi.

7. Wadah kopi yang telah matang, akan ditempatkan di sebelah kiri.

8. Wadah kopi yang tidak teridentifikasi atau setengah matang, akan di tempatkan di antara wadah yang matang dan belum matang.

9. Wadah kopi yang telah matang, akan ditempatkan di sebelah kiri dan pseucode dituliskan dengan menggunakan dengan jenis huruf Courier New10-point.

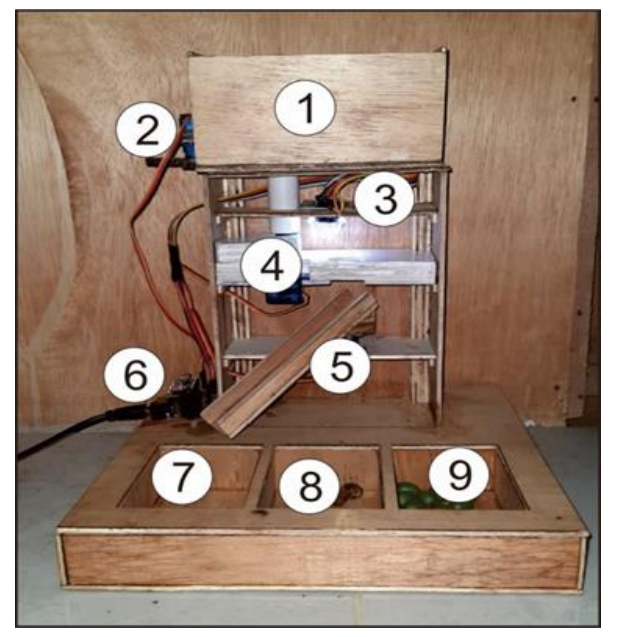

Gambar 5. Hasil Alat pemisah buah kopi

Untuk mengatur sensor warna tcs230 akan ditetapkan beberapa jenis warna kopi yang akan 
dilakukan pengklasifikasian warna dengan mengambil beberapa sampel warna dari buah kopi, untuk menampilkan citra dari warna kopi kami mengunakan satuan ukur RGB yaitu merah (Red), hijau (Green), danbiru (Blue)

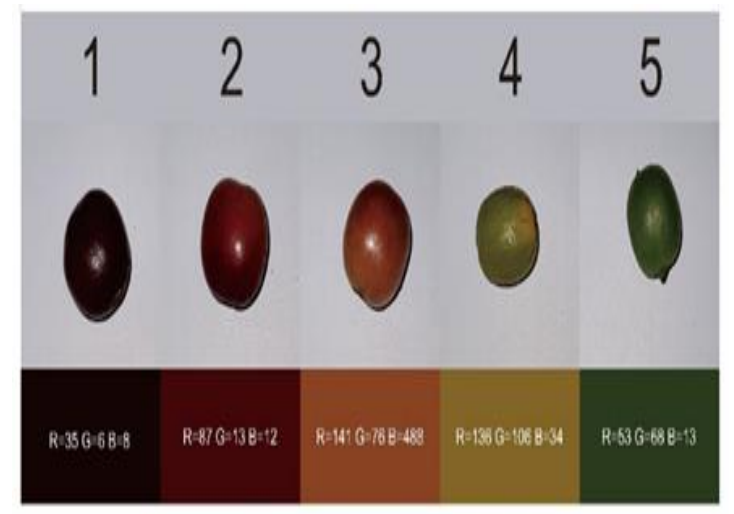

Gambar 6. Sampel warna buah

Keterangan gambar dari sampel warna buah kopi yaitu :

1. Warna pertama, dengan nilai $\mathrm{R}=35 \mathrm{G}=6 \mathrm{~B}=8$ kopi dikategorikan sudah sangat matang dengan kulit berwarna merah gelap,

2. Warna kedua, dengan nilai $\mathrm{R}=87 \mathrm{G}=13 \mathrm{~B}=12$ kopi dikategorikan sudah sangat matang dengan kulit berwarna merah gelap

3. Warna ketiga, dengan nilai $\mathrm{R}=141 \mathrm{G}=76 \mathrm{~B}=48$ kopi dikategorikan mendekati kematangan sempurna dengan kulit berwarna orange gelap

4. Warna keempat, dengan nilai $\mathrm{R}=136 \mathrm{G}=106$ $\mathrm{B}=34$ kopi dikategorikan belum matang dengan kulit berwarna kuning gelap

5. Warna kelima, dengan nilai $\mathrm{R}=53 \mathrm{G}=68 \mathrm{~B}=13$ kopi dikategorikan belum matang dengan kulit berwarna hijau gelap.

Maka diperoleh data dari pembacaan sensor warna tcs 230 seperti pada tabel 1.
Tabel 1. Pembacaan sensor buah kopi yang berwarna merah

\begin{tabular}{cl}
\hline No. & \multicolumn{1}{c}{ Data sensor } \\
\hline 1 & $\mathrm{R}=73 \mathrm{G}=100 \mathrm{~B}=65$ \\
2 & $\mathrm{R}=68 \mathrm{G}=102 \mathrm{~B}=72$ \\
3 & $\mathrm{R}=74 \mathrm{G}=101 \mathrm{~B}=58$ \\
4 & $\mathrm{R}=74 \mathrm{G}=97 \mathrm{~B}=73$ \\
5 & $\mathrm{R}=75 \mathrm{G}=103 \mathrm{~B}=73$ \\
6 & $\mathrm{R}=74 \mathrm{G}=103 \mathrm{~B}=73$ \\
7 & $\mathrm{R}=74 \mathrm{G}=103 \mathrm{~B}=73$ \\
8 & $\mathrm{R}=71 \mathrm{G}=107 \mathrm{~B}=76$ \\
9 & $\mathrm{R}=74 \mathrm{G}=102 \mathrm{~B}=72$ \\
10 & $\mathrm{R}=76 \mathrm{G}=104 \mathrm{~B}=73$ \\
Kesimpulan & $\mathrm{R}=68 \sim 76 \mathrm{G}=97 \sim 107 \mathrm{~B}=58 \sim 76$
\end{tabular}

Pada tabel 1 diperoleh kesimpulan data $\mathrm{R}=68$ $\sim 76 \mathrm{G}=97 \sim 107 \mathrm{~B}=58 \sim 76$

Tabel 2. Pembacaan sensor buah kopi yang berwarna hijau

\begin{tabular}{|c|c|}
\hline NO & Data Sensor \\
\hline 1 & $\mathrm{R}=85 \mathrm{G}=93 \mathrm{~B}=72$ \\
2 & $\mathrm{R}=84 \mathrm{G}=92 \mathrm{~B}=71$ \\
3 & $\mathrm{R}=86 \mathrm{G}=94 \mathrm{~B}=66$ \\
4 & $\mathrm{R}=81 \mathrm{G}=96 \mathrm{~B}=73$ \\
5 & $\mathrm{R}=89 \mathrm{G}=98 \mathrm{~B}=75$ \\
6 & $\mathrm{R}=85 \mathrm{G}=93 \mathrm{~B}=72$ \\
7 & $\mathrm{R}=85 \mathrm{G}=94 \mathrm{~B}=72$ \\
8 & $\mathrm{R}=80 \mathrm{G}=95 \mathrm{~B}=73$ \\
9 & $\mathrm{R}=85 \mathrm{G}=93 \mathrm{~B}=72$ \\
10 & $\mathrm{R}=88 \mathrm{G}=91 \mathrm{~B}=75$ \\
\hline Kesimpulan & $\mathrm{R}=81 \sim 89 \mathrm{G}=90 \sim 98 \mathrm{~B}=66 \sim 75$ \\
\hline
\end{tabular}

Pada Tabel 2 diperoleh kesimpulan data $\mathrm{R}=$ 81 89 $\mathrm{G}=90 \sim 98 \mathrm{~B}=66 \sim 75$. Nilai $\mathrm{R}, \mathrm{G}$ dan $\mathrm{B}$ diperoleh dari rentang anka tertinggi dan terenda misalnya $\mathrm{R}=68 \sim 76$ nilai 68 adalah sampel data $\mathrm{R}$ yang paling rendah dan nilai 76 disebelah kanan adalah data $\mathrm{R}$ yang tertinggi nilainya begitu pula 
proses pengabilan data dari $\mathrm{G}$ dan $\mathrm{B}$, proses pengambilan data dengan cara ini dilakukan agar kita dapat menentukan kondisi warna kopi berdasarkan selang warna yang di filter menggunakan metode pemrogram kondisi IF,

Tabel 3 Hasil Pengujian Sensor Tes230

\begin{tabular}{|c|c|c|c|c|}
\hline No & Warna & Output R & Output G & Output B \\
\hline \multirow{9}{*}{1} & \multirow{9}{*}{ Merah } & $\mathrm{R}=73$ & $\mathrm{G}=100$ & $\mathrm{~B}=65$ \\
\hline & & $\mathrm{R}=68$ & $\mathrm{G}=102$ & $B=72$ \\
\hline & & $\mathrm{R}=74$ & $\mathrm{G}=101$ & $\mathrm{~B}=58$ \\
\hline & & $\mathrm{R}=74$ & $\mathrm{G}=97$ & $B=73$ \\
\hline & & $\mathrm{R}=75$ & $\mathrm{G}=103$ & $B=73$ \\
\hline & & $\mathrm{R}=74$ & $\mathrm{G}=103$ & $B=73$ \\
\hline & & $\mathrm{R}=74$ & $\mathrm{G}=103$ & $B=73$ \\
\hline & & $\mathrm{R}=71$ & $\mathrm{G}=107$ & $B=76$ \\
\hline & & $\mathrm{R}=74$ & $\mathrm{G}=102$ & $B=72$ \\
\hline \multirow{11}{*}{2} & \multirow{11}{*}{ Hijau } & $\mathrm{R}=76$ & $\mathrm{G}=104$ & $\mathrm{~B}=73$ \\
\hline & & $\mathrm{R}=85$ & $\mathrm{G}=93$ & $\mathrm{~B}=72$ \\
\hline & & $\mathrm{R}=84$ & $\mathrm{G}=92$ & $B=71$ \\
\hline & & $\mathrm{R}=86$ & $\mathrm{G}=94$ & $B=66$ \\
\hline & & $\mathrm{R}=81$ & $\mathrm{G}=96$ & $B=73$ \\
\hline & & $\mathrm{R}=89$ & $\mathrm{G}=94$ & $\mathrm{~B}=75$ \\
\hline & & $\mathrm{R}=85$ & $\mathrm{G}=93$ & $\mathrm{~B}=72$ \\
\hline & & $\mathrm{R}=85$ & $\mathrm{G}=94$ & $\mathrm{~B}=72$ \\
\hline & & $\mathrm{R}=80$ & $\mathrm{G}=95$ & $B=73$ \\
\hline & & $\mathrm{R}=85$ & $\mathrm{G}=93$ & $B=75$ \\
\hline & & $\mathrm{R}=88$ & $\mathrm{G}=91$ & $\mathrm{~B}=75$ \\
\hline
\end{tabular}

Pada pengamatan warna buah kopi, Terlihat bahwa pada warna merah persentase tertinggi pada output $\mathrm{G}$ dengan nilai tertinggi dari 10 data adalah 107, warna hijau persentase tertinggi pada output $G$ dengan nilai 96, dengan demikian warnah merah kopi memiliki rentang nilai $G$ yang lebih besar daripada nilai $G$ pada kopi yang berwarna hijau, sedangkan nilai $\mathrm{R}$ pada buah yang berwarna merah lebih renda daripada buah yang warna hijau maka dariitu peneliti menyimpulkan bahawa warna kopi dapat dibedahkan dengan mengambil rentang warna dari kedua buah kopi.

\section{KESIMPULAN}

Berdasarkan hasil penelitian dan pembahasan yang telah diuraikan, maka dapat di tarik kesimpulan bahwa Sensor Tcs230 yang dibangun dapat bekerja dengan baik dan hasil implementasi menunjukkan bahwa tingkat akurasi alat sangat tergantung beberapa hal seperti pencahayaan, jenis benda berwarna yang akan dideteksi, jarak antara sensor dengan obyek warna. Pembuatan system kendali untuk otomasi alat pemisah buah kopi berdasarkan warna dengan sensor warna tcs 230 telah berhasil memisahkan buah kopi kedalam wadah yang telah ditentukan.

\section{UCAPAN TERIMA KASIH}

Mengucapkan terima kasih kepada pihak yang terlibat pada penelitian ini dan kepada rekan-rekan dosen yang mendukung sehingga terselesainya penelitian ini. 


\section{DAFTAR PUSTAKA}

[1] Dimas Rizki Radityo, dkk. "Alat Penyortir dan Pengecekan Kematangan Buah Menggunakan Sensor Warna", Jurnal Teknik Komputer Vol. 20 No.2 pp.88-92, Agustus 2012

[2] Sunu Jatmika, dkk. "Rancang Bangun Alat Pendeteksi Kematangan Buah Apel dengan Menggunakan Metode Image Processing Berdasarkan Komposisi Warna", Jurnal Ilmiah Teknologi dan Informasi ASIA Vol. 8 No 1,Februari 2014

[3] Kadir, Abdul, Arduino Dan Sensor Tuntunan Praktis Mempelajari Penggunaan Sensor. Penerbit Andi Offset Jogyakarta. 2018

[4] W Saptaji Handayani,. Mudah Belajar Miktokontroller dengan Arduino., Penerbit Widya Media Jawa Timur. 2018.

[5] Wicaksono Fajar Mochamad, Aplikasi Arduino dan Sensor., Penerbit Informatika Bandung. 2019.

[6] Syahwil Muhammad., Panduan Mudah Belajar Arduino Menggunakan Simulasi Proteus. Penerbit Andi Offset Jogyakarta. 2019. 